\title{
Rootstock effects on scion growth and reproduction in 8-year-old grafted loblolly pine
}

\author{
K.J.S. Jayawickrama, S.E. McKeand, and J.B. Jett
}

\begin{abstract}
Contributions of sites, rootstocks, and scion clones (and the interactions between these factors) to scion growth and reproduction were studied in loblolly pine (Pinus taeda L.). Twenty-five full-sib families were used as rootstocks. Six scion clones were grafted on them in all combinations. Study sites were three seed orchards in the southeastern United States; trees were measured 8 years after grafting. Scion elongation, diameter at breast height (DBH) of the main leader, crown diameter, cone counts, and number of male and female strobili were measured at all sites. Crown diameter and tree height were combined into a crown volume index. Highly significant differences existed among scion clones for all traits. When analyzed over all three sites, the only trait with significant rootstock effects was DBH. There were significant rootstock $\times$ scion interactions for total scion elongation, crown volume index, and DBH and significant site $\times$ scion interactions for strobili counts and cone count. In analyses by clone, rootstock effects were expressed differently in the different clones. There were significant rootstock effects for three traits in each of three clones and no effects at all in two clones. For all traits the largest variance component was for either site or scion clone. Components for rootstocks were small or zero. These results show that the scion clone and site have more control on scion growth and reproduction of grafted loblolly pine than the rootstock. The study did not identify full-sib families that (as rootstocks) would signficantly reduce scion elongation or signficantly increase cone production, for all six scion clones at all three sites.
\end{abstract}

Résumé : Les auteurs ont étudié les effets du site, du porte-greffe et de la source clonale de greffes, ainsi que les interactions entre ces facteurs, sur la croissance de la greffe et l'effort de reproduction chez le pin à encens (Pinus taeda L.). Un total de 25 descendances biparentales furent utilisées comme porte-greffes, et des greffes de six clones différents furent greffées sur ces derniers selon toutes les combinaisons possibles. Les sites d'étude étaient représentés par trois vergers à graines situés dans le Sud-Est des États-Unis. Les arbres furent mesurés huit ans après le greffage. Les auteurs ont mesuré l'accroissement en hauteur de la greffe, le diamètre à hauteur de poitrine (DHP) de la tige principale et le diamètre de la cime. Le diamètre de la cime et la hauteur des arbres furent combinés en un indice de volume de la cime. Le nombre de cônes ainsi que le nombre de fleurs mâles et femelles ont également été estimés. Des différences hautement significatives pour tous les caractères furent notées parmi les sources clonales de greffes. Le DHP était le seul caractère sur lequel les porte-greffes avaient un effet significatif lorsque les trois sites étaient analysés de façon combinée. Des interactions significatives entre l'effet dû aux porte-greffes et celui dû aux sources clonales de greffes furent notées pour l'accroissement en hauteur de la greffe, l'indice de volume de la cime et le DHP. Des interactions significatives furent également notées entre l'effet dû aux sites et celui dû aux sources clonales de greffes pour le nombre de fleurs et le nombre de cônes. L'analyse individuelle des différentes sources clonales de greffes a révélé une expression différentielle des effets dus aux porte-greffes d'une source clonale à l'autre. À ce sujet, une variation significative due aux porte-greffes a été notée pour trois caractères, et cela pour chacune de trois sources clonales de greffes, mais aucune variation due aux porte-greffes ne fut notée pour deux sources clonales. Pour tous les caractères, la plus grande composante de variance fut notée pour l'effet dû aux sites ou celui dû aux sources clonales de greffes. Les composantes reliées à l'effet dû aux porte-greffes étaient faibles ou nulles. Ces résultats démontrent que la source clonale de greffes et le site ont plus d'effet que le porte-greffe sur la croissance des greffes et l'effort de reproduction des pins à encens greffés. L'étude n'a pas permis d'identifier des descendances biparentales qui, lorsqu'utilisées comme source de porte-greffes, pourraient diminuer de façon significative l'accroissement en hauteur des greffes ou augmenter de façon significative la production de cônes et ce, pour les trois sites de cette étude et les six sources clonales de greffes étudiées. [Traduit par la Rédaction]

Received June 3, 1997. Accepted July 31, 1997.

K.J.S. Jayawickrama ${ }^{1}$ and S.E. McKeand. Department of Forestry, North Carolina State University, Raleigh, NC 27695-8002, U.S.A.

J.B. Jett. College of Forest Resources, North Carolina State University, Raleigh, NC 27695-8002, U.S.A.

1 Author to whom all correspondence should be addressed. Present address: Genetics and Tree Improvement, New Zealand Forest Research Institute Ltd., Private Bag 3020, Rotorua, New Zealand.

\section{Introduction}

Loblolly pine (Pinus taeda L.) seed orchards are established in the southeastern United States primarily using grafts. Rootstock plants are usually seedlings obtained from a mix of seed from seed orchards. Using select rootstock families or clones is rare, apart from grafting some incompatible clones onto seedlings from the same clone.

Rootstocks are an effective tool for influencing scion behavior and performance in fruit tree species (Rom and Carlson 1987). The horticultural literature has many reports of rootstock effects on scions, e.g., on tree vigor (Roose et al. 1989; 
Table 1. Form of ANOVA and expected mean squares for the overall study.

\begin{tabular}{lll}
\hline Source $^{a}$ & \multicolumn{1}{c}{$\mathrm{df}$} & \multicolumn{1}{c}{ Expected mean squares } \\
\hline $\mathrm{S}$ & $(s-1)=2$ & $\sigma^{2}+23.3 \sigma^{2}{ }_{\mathrm{SC}}+5.58 \sigma^{2}{ }_{\mathrm{RS}}+139.6 \sigma^{2} \mathrm{~S}$ \\
$\mathrm{R}$ & $(r-1)=24$ & $\sigma^{2}+2.82 \sigma_{\mathrm{RC}}^{2}+5.62 \sigma^{2}{ }_{\mathrm{RS}}+16.9 \sigma^{2}{ }_{\mathrm{R}}$ \\
$\mathrm{C}$ & $(c-1)=5$ & $\sigma^{2}+2.79 \sigma_{\mathrm{RC}}^{2}+23.2 \sigma^{2}{ }_{\mathrm{SC}}+69.6 \sigma^{2}{ }_{\mathrm{C}}$ \\
$\mathrm{S} \times \mathrm{R}$ & $(s-1)(r-1)=48$ & $\sigma^{2}+5.67 \sigma_{\mathrm{SR}}^{2}$ \\
$\mathrm{~S} \times \mathrm{C}$ & $(s-1)(c-1)=10$ & $\sigma^{2}+23.4 \sigma^{2}{ }_{\mathrm{SC}}$ \\
$\mathrm{R} \times \mathrm{C}$ & $(r-1)(c-1)=120$ & $\sigma^{2}+2.87 \sigma_{\mathrm{RC}}^{2}$ \\
Residual & 224 & $\sigma^{2}$ \\
Total & 434 & \\
\hline
\end{tabular}

Note: Site, rootstock, and clone main effects are random. The degrees of freedom apply to the number of observations 8 years after grafting.

${ }^{a} \mathrm{~S}$, site; R, rootstock family; $\mathrm{C}$, scion clone.

Westwood et al. 1976), yield (Roose et al. 1989; Westwood et al. 1976), and phenology (Layne et al. 1977; Westwood 1970; Young and Houser 1980). While research in conifers used in forestry is nowhere as extensive or comprehensive (Jayawickrama et al. 1991), there have been reports of marked differences in scion growth, attributable to rootstocks (Schmidtling 1983a; Melchior 1984; Sniezko 1986; Karlsson and Woods 1992). However, this effect was not seen in other cases (van den Driessche 1974; Sniezko 1986). Similarly, there have been effects reported on reproduction (Schmidtling 1983a) whereas in other studies, no effect was reported (Dyson 1975; Guldager 1972). Little has been reported for conifers on rootstock effects on scion phenology, such as on onset of dormancy (Jayawickrama et al. 1991).

Rootstock effects, if they exist, could be important in tree improvement. First, stimulation of seed production would be very valuable in seed orchards. Water stress and other dormancyinducing treatments are used to encourage dormant bud formation earlier than normal (Greenwood 1981). If some rootstocks cause early dormancy, they would allow more time to initiate strobili and promote strobili initiation. Second, a reduction of scion vigor could also be important, since harvesting cones is the greatest expense in managing loblolly pine seed orchards. Ramets can grow to $30 \mathrm{~m}$ or more, creating a need for large and expensive lift equipment. Rootstocks that reduce scion vigor without reducing seed production would be of great value.

More fundamental questions can be asked about the complex system of a grafted conifer, such as the relative effects of rootstocks and scions on scion behavior. While there are some estimates (Vyvyan 1934; Rives 1971; Moore 1975), the information is not extensive, even for fruit tree species, and is very scarce in forestry species. Another is how stable is the effect of a rootstock over sites (different climatic regions, soil types, etc.). A lack of rootstock $\times$ site interactions would simplify the testing, production, and use of specific rootstocks. While results in Douglas-fir (Pseudotsuga menziesii (Mirb.) Franco) do suggest such a lack of interactions in the case of graft incompatibility (Copes 1982), there is little information on Pinus species.

To select among rootstocks for operational use in seed orchards, an adequate genetic sample must be evaluated in a rigorous experimental design for a sufficient period (until the ramets reach commercial production) and over several envi- ronments. Few such studies have been conducted on loblolly pine (Jayawickrama et al. 1991).

This study was therefore undertaken to (1) test the effects of rootstocks, scion clones, and sites (and the interactions between these factors) on scion growth and reproduction in loblolly pine, (2) estimate the relative contributions to the variance in each trait by scion clones, rootstocks, sites, and the interactions between these factors, and (3) identify any full-sib families with useful properties as rootstocks.

\section{Methods}

\section{Experimental layout}

The study was installed at three seed orchards of members of the North Carolina State University - Industry Cooperative Tree Improvement Program (NCSU-ICTIP): Jefferson Smurfit Corp. (JSC), Bowater Corp. (BC), and South Carolina Commission of Forestry (SCCF). These orchards were at Brewton, Ala. $\left(31^{\circ} 10^{\prime} \mathrm{N}, 87^{\circ} 05^{\prime} \mathrm{W}\right)$, Oak Park, Ga. $\left(32^{\circ} 20^{\prime} \mathrm{N}, 82^{\circ} 10^{\prime} \mathrm{W}\right)$, and Tillman, S.C. $\left(32^{\circ} 24^{\prime} \mathrm{N}\right.$, $\left.81^{\circ} 6^{\prime} \mathrm{W}\right)$, respectively. Scions from six clones, selected for fast growth and routinely used in second-generation orchards of the NCSU-ICTIP, were grafted on 25 full-sib rootstock families. Twenty of these families were selected from the slowest growing families of the first-generation breeding program of the Cooperative (in the hope of finding "dwarfing" rootstocks), while the other five were fastgrowing families. Two of the 25 rootstock families had one parent in common; all the others were unrelated. The scion clones were all unrelated to each other and the rootstock families. A list of the rootstock families and scion clones and their height performance levels are given in Jayawickrama (1991).

The rootstocks were raised from seed in $164-\mathrm{cm}^{3} \mathrm{RL}$ Super Cells starting in June 1986 and planted in fall 1986 at $4.6 \times 9.1 \mathrm{~m}$ spacing. At each site, 12 trees were planted per rootstock family in a completely randomized design. In the spring of 1987, $150 \mathrm{~g}$ of ammonium nitrate was applied per tree. The trees were grafted in February and March 1988 with scions from ramets maintained at the NCSU Genetics Garden in Raleigh, N.C. Fifty grafts were made per scion clone per site (two per rootstock-scion combination). Standard wax grafting techniques (White et al. 1983) were used, and where possible, grafts were made at the same height on the rootstock. Weeds and pests were controlled as needed. Rootstock foliage was removed in February 1989 and standard seed orchard culture applied from then on (Jett 1986).

Total height, diameter at breast height (DBH, $1.4 \mathrm{~m}$ ), and crown diameter of the grafted trees were measured yearly at all three sites. Scion elongation was calculated as the difference between total height and the height of the graft union. The numbers of male strobili and female strobili were counted when the ramets were 2,3 , and 4 years old. Cone counts were taken at ages 7 and 8; cones were not counted at JSC at age 7 due to a poor cone crop. Crown diameter and total height were combined to form a crown volume index, which was the volume (cubic metres) of the crown (the crown being considered a cone starting at $1.5 \mathrm{~m}$ from the ground). Data are presented in this paper for the following six traits at all three sites: total scion elongation, DBH, crown volume index, and cone count (all at age 8) and total number of female strobili and total number of male strobili (both at years 2-4). The age 7 cone count is also briefly discussed.

\section{Data analyses}

The data were analyzed as a randomized complete block design for a combined analysis over locations, with the blocks being the three sites. Sites, rootstock families, and scion clones were considered random effects. Analysis of variance (ANOVA) was conducted on rootstock family $\times$ scion clone means within a site. The form of the ANOVA and the expected mean squares, obtained by using the RANDOM 
Table 2. Mean values for all traits (cone and strobili count data are untransformed).

\begin{tabular}{lcccc}
\hline Trait & $\begin{array}{c}\text { Overall } \\
\text { mean }\end{array}$ & $\begin{array}{c}\text { Range of rootstock } \\
\text { family means }\end{array}$ & $\begin{array}{c}\text { Range of scion } \\
\text { clone means }\end{array}$ & $\begin{array}{c}\text { Range of } \\
\text { site means }\end{array}$ \\
\hline Total scion elongation $(\mathrm{m})$, year 8 & 9.55 & $9.20-9.85$ & $9.19-10.05$ & $8.51-10.15$ \\
DBH $(\mathrm{cm})$, year 8 & 22.7 & $20.9-23.9$ & $21.1-24.6$ & $20.7-24.0$ \\
Crown volume index $\left(\mathrm{m}^{3}\right)$, year 8 & 134.6 & $116.9-154.8$ & $112.2-171.4$ & $66.1-181.4$ \\
Cone count, year 8 & 41.1 & $27.8-60.8$ & $6.88-116.8$ & $28.7-48.8$ \\
Cumulative total no. of female strobili, years 2-4 & 73.4 & $49.0-107.8$ & $7.86-184.8$ & $51.5-95.9$ \\
Cumulative total no. of male strobili, years 2-4 & 83.2 & $62.6-124.9$ & $5.76-221.0$ & $47.5-120.3$ \\
\hline
\end{tabular}

Table 3. Mean square estimates and (within parentheses) estimates of the probability of a larger $F$-value.

\begin{tabular}{|c|c|c|c|c|c|c|c|c|c|c|}
\hline \multirow{2}{*}{$\frac{\text { Source }^{a}}{\mathrm{~S}}$} & \multirow{2}{*}{$\frac{\mathrm{df}}{2}$} & \multirow{2}{*}{$\begin{array}{c}\begin{array}{c}\text { Total scion } \\
\text { elongation }(\mathrm{m}), \\
\text { year } 8\end{array} \\
120.30(\mathbf{0 . 0 0 0 1})\end{array}$} & \multicolumn{2}{|c|}{$\begin{array}{c}\text { Crown } \\
\text { volume index, } \\
\text { year } 8\end{array}$} & $\begin{array}{c}\text { DBH }(\mathrm{cm}), \\
\text { year } 8 \\
\end{array}$ & \multicolumn{2}{|c|}{$\begin{array}{c}\text { Cone count, } \\
\text { year } 8^{b}\end{array}$} & \multicolumn{2}{|c|}{$\begin{array}{l}\text { Total no. of } \\
\text { female strobili, } \\
\text { years } 2-4^{b}\end{array}$} & $\begin{array}{l}\text { Total no. of } \\
\text { male strobili, } \\
\text { years } 2-4^{b}\end{array}$ \\
\hline & & & 531191 & $(0.0001)$ & $450.7 \quad(\mathbf{0 . 0 0 0 1})$ & 95.2 & $(0.0968)$ & 416.3 & $(0.0001)$ & $\begin{array}{ll}513.8 \quad(\mathbf{0 . 0 0 0 6}) \\
\end{array}$ \\
\hline $\mathrm{C}$ & 5 & $6.56(\mathbf{0 . 0 0 0 1})$ & 31462 & $(0.0001)$ & $91.0 \quad(\mathbf{0 . 0 0 0 1})$ & 612.2 & $(0.0001)$ & 1732.4 & $(0.0001)$ & $1261.20(\mathbf{0 . 0 0 0 1})$ \\
\hline $\mathrm{S} \times \mathrm{R}$ & 48 & $0.21(0.5923)$ & 735.0 & $(0.7219)$ & $1.64(0.9365)$ & 2.2 & $(0.7360)$ & 4.6 & $(0.0385)$ & $7.8 \quad(0.1421)$ \\
\hline Residual & 224 & 0.22 & 850.6 & & 2.37 & 2.6 & & 3.2 & & 6.3 \\
\hline$R^{2}$ & & 0.89 & 0.89 & & 0.81 & 0.88 & & 0.9 & & 0.87 \\
\hline
\end{tabular}

Note: Data analyzed as a randomized complete block design (sites, rootstocks, and clones considered random). Bold numbering indicates $p$-values $\leq 0.05$.

${ }^{a} \mathrm{~S}$, site; R, rootstock; C, scion clone.

${ }^{b}$ Data were subject to square-root transformation prior to analysis.

Table 4. ANOVA, by site, for the three reproduction traits.

\begin{tabular}{|c|c|c|c|c|c|c|c|}
\hline \multirow[b]{2}{*}{ Source } & \multirow[b]{2}{*}{ df } & \multicolumn{6}{|c|}{ Site } \\
\hline & & \multicolumn{2}{|r|}{$\mathrm{BC}$} & \multicolumn{2}{|c|}{ JSC } & \multicolumn{2}{|c|}{ SCCF } \\
\hline \multicolumn{8}{|l|}{ Cone count, year 8} \\
\hline Scion clone & 5 & 75.1 & $(0.0001)$ & 243.7 & $(0.0001)$ & 209.9 & $(0.0001)$ \\
\hline Rootstock family & 24 & 2.4 & $(0.114)$ & 3.1 & $(0.777)$ & 2.5 & $(0.144)$ \\
\hline Residual & 116 & 1.6 & & 4.0 & & 1.8 & \\
\hline$R^{2}$ & & 0.82 & & 0.7 & & 0.87 & \\
\hline \multicolumn{8}{|c|}{ Total no. of female strobili, years $2-4$} \\
\hline Scion clone & 5 & 687.8 & $(0.0001)$ & 505.6 & $(0.0001)$ & 625.9 & $(0.0001)$ \\
\hline Rootstock family & 24 & 3.8 & $(0.4375)$ & 5.4 & $(0.116)$ & 6.3 & $(0.0002)$ \\
\hline Residual & 47 & 3.7 & & 3.8 & & 2.3 & \\
\hline$R^{2}$ & & 0.85 & & $0.8^{\prime}$ & & 0.92 & \\
\hline \multicolumn{8}{|c|}{ Total no. of male strobili, years $2-4$} \\
\hline Scion clone & 5 & 443.5 & $(\mathbf{0 . 0 0 0 1 )}$ & 317.8 & $(0.0001)$ & 594.6 & $(0.0001)$ \\
\hline Rootstock family & 24 & 9.4 & $(0.014)$ & 10.3 & $(\mathbf{0 . 0 1 1})$ & 10.3 & $(0.586)$ \\
\hline Residual & 47 & 4.9 & & 5.4 & & 12.1 & \\
\hline$R^{2}$ & & 0.80 & & 0.7 & & 0.70 & \\
\hline
\end{tabular}

Note: Values given are mean square estimates and (within parentheses) estimates of the probability of a larger $F$-value. Data analyzed as a randomized complete block design (sites and rootstocks considered to be random). Bold numbering indicates $p$-values $\leq 0.05$. Data were subject to square-root transformation prior to analysis.

option in PROC GLM (SAS Institute Inc. 1989), are given in Table 1. The noninteger coefficients result from having a slight imbalance by age 8 ( 434 of the original 450 site-rootstock-clone combinations, 756 of the original 900 grafts, were available for measuring by then).

Contributions of the different terms were calculated by estimating the variance component attributed to each term using PROC VARCOMP method = type 1 (SAS Institute Inc. 1989). All factors (sites (S), rootstock families (R), and scion clones (C)) were considered random for this calculation. The relative contribution of each factor was calculated by dividing the variance component by the total variance. The total variance was calculated as follows:

$$
\begin{aligned}
\text { Total variance }= & (\text { Var }) \mathrm{S}+(\text { Var }) \mathrm{R}+(\text { Var }) \mathrm{C}+(\text { Var }) \mathrm{S} \\
& \times \mathrm{R}+(\text { Var }) \mathrm{S} \times \mathrm{C}+(\text { Var }) \mathrm{R} \times \mathrm{C} \\
& + \text { residual variance }
\end{aligned}
$$

The rootstocks were not a random sample of available families but selected for a specific trait (height growth). However, a test of the effect of rootstock family type showed no statistical difference between the previously designated fast-growing and slow-growing rootstock families (for the traits measured on scions). Thus the families were considered as drawn from a population of families (i.e., a random effect for ANOVA and variance components). 


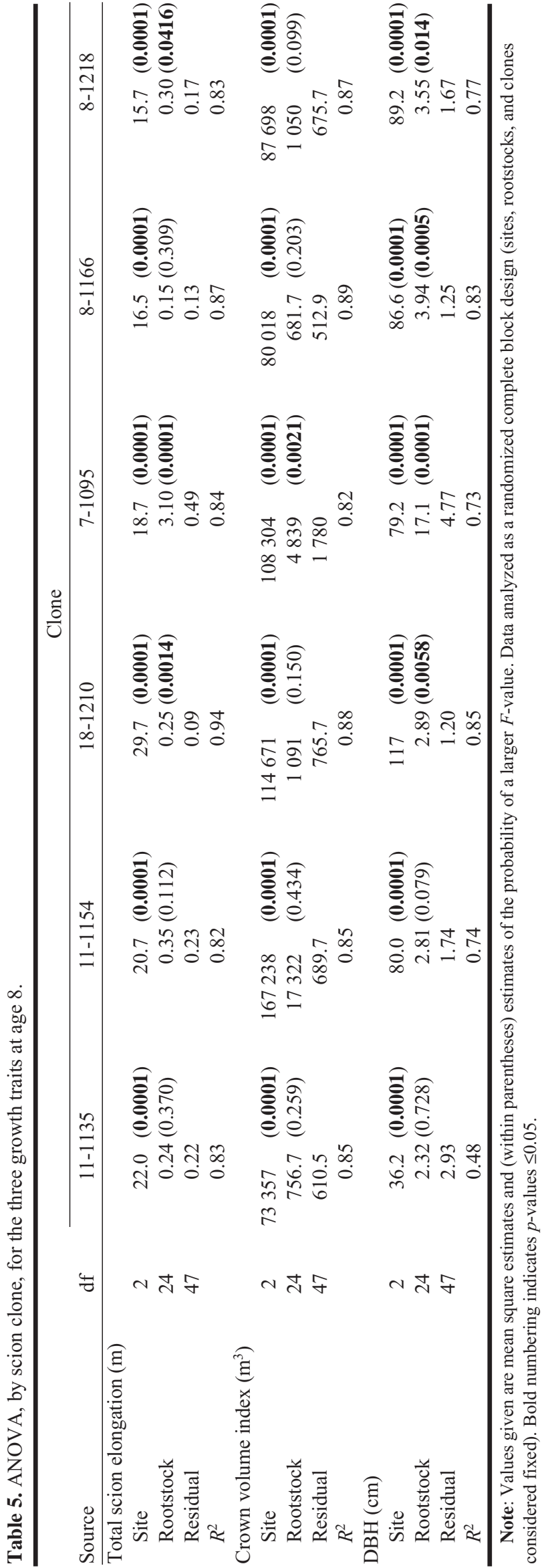

Prior to data analyses, the observed residuals were tested for normality using PROC UNIVARIATE (SAS Institute Inc. 1989). Residuals for the original data differed significantly from a normal distribution, but when site $\times$ rootstock $\times$ clone means were used the residuals were well approximated by a normal distribution. An earlier analysis showed that the site $\times$ rootstock $\times$ clone interaction was nonsignificant for all traits and contributed very little to the variance. Thus, we pooled this term with experimental error. Strobili counts and cone counts showed deviations from a normal distribution even on a means basis. Counts were therefore subjected to the square root transformation (before taking means) for ANOVA and calculating variance components. When significant interactions were found the data were reanalyzed by the term involved in the interaction (e.g., by site for cone count).

\section{Results}

Mean values for all traits over the three sites (overall means, rootstock family means, scion clone means, and site means) are given in Table 2 . The range for rootstock family means was similar to that for scion clones, except for cone counts and the number of strobili. The largest ranges (for both rootstock families and scion clones) were for the number of strobili. The range for site means was largest for crown volume index.

Scion clones had very significant effects $(p<0.001)$ on all traits (Table 3 ). There were significant differences among sites $(p<0.001)$ for all traits. Rootstock effects were statistically significant only for DBH $(p<0.01)$. The site $\times$ clone interaction was significant $(p<0.001)$ for the three reproduction traits, while the site $\times$ rootstock interaction was significant for only one trait. The rootstock $\times$ clone interaction was significant $(p<0.001)$ for the three measures of vegetative growth.

When reproductive traits were analyzed by site, clone effects were highly significant at all sites (Table 4). Further, there were significant rootstock effects for total male strobili at BC and JSC $(p<0.02)$ and for total female strobili at SCCF $(p<0.001)$. When the growth traits were analyzed by clone, site effects were highly significant in all clones (Table 5). Further, clone 7-1095 showed significant rootstock effects for all three traits $(p<0.001)$. Clones $18-1210$ and 8-1218 showed significant rootstock effects for scion elongation and DBH $(p<0.05)$. Analysis of reproduction by clone showed significant rootstock effects for total female strobili in clone 8-1218, for total male strobili in clone 18-1210, and for both total male strobili and cone count in clone 8-1166 (data not shown).

Scion clones accounted for $6.2-78 \%$ of the variance, sites for $3.6-71 \%$, and rootstocks for less than $4 \%$ (Table 6). The site $\times$ clone interaction contributed at most $10 \%$ of the variance. The site $\times$ rootstock interaction contributed very little to the variance.

Age 7 cone production at the two sites measured was lower than age 8 production for the same two sites (14.1 cones per ramet versus 38.7). However, results of the hypothesis tests were the same as for age 8: statistically significant site, scion clone, site $\times$ clone effects with the other effects not significant (data not shown).

\section{Discussion}

Statistically significant differences were found among scion clones in all six traits measured (Tables 3 and 4 ) with very low $p$-values. Although the clones were all selected for growth rate 
Table 6. Variance component estimates and (within parentheses) each term as a percentage of the sum of the variance components.

\begin{tabular}{|c|c|c|c|c|c|c|c|}
\hline Source $^{a}$ & df & $\begin{array}{c}\text { Total scion } \\
\text { elongation }(\mathrm{m}) \text {, } \\
\text { year } 8\end{array}$ & $\begin{array}{c}\text { Crown } \\
\text { volume index, } \\
\text { year } 8\end{array}$ & $\begin{array}{c}\mathrm{DBH}(\mathrm{cm}), \\
\text { year } 8\end{array}$ & $\begin{array}{c}\text { Cone count, } \\
\text { year } 8^{b}\end{array}$ & $\begin{array}{c}\text { Total no. of } \\
\text { female strobili, } \\
\text { years } 2-4^{b}\end{array}$ & $\begin{array}{c}\text { Total no. of } \\
\text { male strobili, } \\
\text { years } 2-4^{b}\end{array}$ \\
\hline $\mathrm{S}$ & 2 & $8372 \quad(63.0)$ & $3781 \quad(71.1)$ & $3.13 \quad(39.3)$ & $0.460(3.59)$ & 2.84 (8.96) & 3.36 (11.3) \\
\hline $\mathrm{R}$ & 24 & $0 \quad(0)$ & $27.6(0.52)$ & (3.98) & $0.133(1.04)$ & $0.051(0.16)$ & $0.111(0.37)$ \\
\hline $\mathrm{C}$ & 5 & $820.8(6.18)$ & $426.8(8.03)$ & 1.17 (14.7) & $8.33 \quad(65.3)$ & $24.8 \quad(78.3)$ & $17.6 \quad(58.9)$ \\
\hline $\mathrm{S} \times \mathrm{C}$ & 10 & $85.0(0.64)$ & $24.5(0.46)$ & $0.020(2.48)$ & $1.27 \quad(10.0)$ & $1.28 \quad(10.0)$ & $0.985(3.31)$ \\
\hline Residual & 224 & $2209 \quad(16.6)$ & $850.5(16.0)$ & $2.37 \quad(29.4)$ & $2.56 \quad(20.1)$ & $3.19(10.1)$ & $6.26 \quad(21.0)$ \\
\hline
\end{tabular}

Note: Data analyzed as a randomized complete block design (sites, rootstocks and clones considered random).

${ }^{a} \mathrm{~S}$, site; R, rootstock; $\mathrm{C}$, scion clone.

${ }^{b}$ Data were subject to square-root transformation prior to analysis.

and used in second-generation seed orchards, they differed considerably in growth rate. They differed even more for reproduction with a 22 -fold difference in female strobilus count (years 2-4) and a 17-fold difference in cone count at year 8 (Table 2). Large clone differences in seed production are typically noted in seed orchards (Schmidtling 1983b; Jett 1986; Blush et al. 1993). Substantial differences have been found among scion clones in previous rootstock studies for scion growth (Bryndum 1965; McKinley 1975; Sniezko 1986), reproduction (Sniezko 1986; Schmidtling 1988), and flushing behavior (Melchior 1984).

Significant differences among sites for five of the six traits (Tables 3 and 5) and site $\times$ clone interactions for four of the six traits (Table 3 ) can be attributed to climatic and soil differences and the response of scion clones to them. The three sites represented a wide longitudinal range. Differences have been found between sites for reproduction (Melchior 1987) and compatibility (Copes 1982) in grafted conifers; the productivity of seed orchards is strongly influenced by location (Jett 1986).

Two clones (11-1135 and 11-1154) had no differences among rootstocks at all. Three clones (7-1095, 8-1166, and 18-1210) showed rootstock effects in three traits and 8-1218 in four traits. This pattern and the significant rootstock $\times$ clone interactions for three traits (cone count, number of male strobili, and number of female strobili, Table 3) indicate a modest potential for matching scion clones to rootstock families to maximize seed production. Such matching would, however, be prohibitive if many clones were used and each clone had to be individually tested on the rootstock families. Previous studies on scion elongation in pine species have not shown significant rootstock $\times$ clone interactions (McKinley 1975; Sniezko 1986).

Rootstocks had relatively little effect on scion behavior when averaged across clones and sites (Tables 3 and 6). It was noteworthy that while there was no effect on scion elongation, there was an effect on DBH. The apparent effect of rootstocks on the number of male strobili (years 2-4) at BC and JSC could be due to an effect on precocity (Table 4). Considering age 2 data only, the rootstock family had a significant effect on number of female strobili (Jayawickrama 1991), and possibly an effect on precocity as well. This effect was not, however, accompanied by an effect on cone count at age 8 . Precocity would be useful in accelerating breeding programs by producing more strobili for controlled crosses in young ramets. Earlier results of this study had shown scion clones to have a very significant effect on the date of onset of dormancy, contributing $9.6 \%$ of the variance, while the contribution of rootstocks to the variance was negligible (Jayawickrama 1991).

Three reasons are proposed as to why the scion clone was more important than the rootstock family in the control of most traits. First, all traits measured were expressed by the scion. It has been suggested that the various parts of a tree are autonomous and the scion maintains its characteristics even when grafted (Wutscher 1989). Apical dominance is an example where a distinct structure of command is set up within a plant, strongly regulating the development of different organs and regions (Hillman 1984). Grafts with scions from older loblolly pine ortets produced more female strobili and grew slower than grafts with scions from 1-year-old seedlings (Greenwood 1984). This followed the pattern in older trees versus seedlings. The stronger scion influence may be because an influence from the rootstock would be exerted indirectly, while the scion genotype influenced it directly. Second, as suggested in Copes (1982), full-sib families were used as rootstocks, while clones were used as scions; thus, while ramets within a scion clone had identical genotypes, there was genetic variation within a rootstock family. Significant rootstock effects were found on several scion traits at age 15-18 months in a study on Pinus caribaea Mor. var. hondurensis Barr. et Golf where clonal rootstocks were used (Haines and Simpson 1994). Third, the number of individuals per scion clone was larger than the numbers per rootstock family. The second and third reasons may have contributed to lower levels of significance among rootstocks.

The second and third issues above were, however, a result of the objectives of the study. Since the main purpose was to screen a reasonable number of rootstocks, there were more rootstock families than scions. Also, rooting ability declines with age in loblolly pine (Greenwood et al. 1991). As a result, it would be difficult to root cuttings of an outstanding rootstock tree (which would typically not have foliage anyway). Thus, for now, a desired rootstock could be reliably propagated vegetatively only if the original donor plant was kept hedged, as hedging can reduce ageing (Greenwood et al. 1991). Given this constraint, the use of full-sib families is the most cost-effective option.

Results with stronger scion effects (compared with rootstock effects) have been reported before, such as for fruit yield in grape (Vitis vinifera L.) (Rives 1971) and numbers of flowers and fruits in apple (Malus domestica Borkh.) (Moore 1975). 
In other studies, the rootstock was more important than the scion, such as for seed yield in common bean (Phaseolus vulgaris L.) (White and Castillo 1989), growth in apple (Vyvyan 1934), and stem dry weight in apple (Moore 1975).

Future studies with clonal material, adequately replicated, may identify trees with desirable properties as rootstocks. Provided the donor had been maintained as a hedge, it may be possible to repropagate these clones, although rooting may be low for some genotypes (Greenwood et al. 1991). These rootstocks may grow more slowly than seedling rootstocks if the hedge was several years from seed. Such maturation of the rootstock could have both desirable and undesirable properties. It is not clear if the benefits would outweigh the costs of such a program.

\section{Conclusions}

The growth and reproduction of grafted loblolly pine were much more strongly controlled by the scion genotype than by the rootstock family, at 8 years from grafting. However, rootstocks did have some effect on growth and reproduction. Site effects were also large, and significant site $\times$ clone interactions and rootstock $\times$ clone interactions were seen in some traits. Rootstock effects were manifested more strongly in some clones than in others. The study did not identify full-sib families that (as rootstocks) would signficantly reduce scion elongation or signficantly increase cone production, for all six scion clones at all three sites.

\section{Acknowledgments}

This work was funded by the North Carolina State University Industry Cooperative Tree Improvement Program. We thank the personnel of Bowater Inc. (especially Mike Powell and Mike Williford), Jefferson Smurfit Corp. (especially Gary Bailey, Bob Loveless, and Fred Raley), and the South Carolina Commission (especially Ray Moody and Howard Shingledecker) for their help. Chris Hunt and Paula Otto (North Carolina State University) provided technical assistance.

\section{References}

Blush, T.D., Bramlett, D.L., and El-Kassaby, Y.A. 1993. Reproductive phenology of seed orchards. In Advances in pollen management. Edited by D.L. Bramlett, G.R. Askew, T.D. Blush, F.E. Bridgwater, and J.B. Jett. U.S. Dep. Agric. Agric. Handb. 698. pp. 15-23.

Bryndum, K. 1965. The effect of the root-stock upon the height growth of Picea abies grafts. Forstl. Forsoegsvaes. Dan. 29: $162-171$.

Copes, D.L. 1982. Field tests of graft compatible Douglas-fir seedling rootstocks. Silvae Genet. 31: 183-187.

Dyson, W.G. 1975. A note on dwarfing of Pinus patula grafts. Silvae Genet. 24: 60-61.

Greenwood, M.S. 1981. Reproductive development in loblolly pine. II. The effect of age, gibberellin plus water stress and out-of-phase dormancy on long shoot behavior. Am. J. Bot. 68: 1184-1190.

Greenwood, M.S. 1984. Phase change in loblolly pine: shoot development as a function of age. Physiol. Plant. 61: 518-522.

Greenwood, M.S., Foster, G.S., and Amerson, H.V. 1991. Vegetative propagation of southern pines. In Forest regeneration manual. Edited by M.L. Duryea and P.M. Dougherty. Kluwer Academic Publishers, Dordrecht, The Netherlands. pp. 75-86.
Guldager, P. 1972. Interprovenance grafting - 4 provenances of Pinus kesiya. Res. Note 12, Division of Forest Research, Zambia. (As cited in For. Abstr. 29: 272.)

Haines, R.J., and Simpson, J.A. 1994. Scion-rootstock relationships with respect to height growth and foliar concentrations of nitrogen and phosphorus in reciprocal grafts of Pinus caribaea var. hondurensis. New For. 8: 71-79.

Hillman, J.R. 1984. Apical dominance. In Advanced plant physiology. Edited by M.B. Wilkins. Pitman Publishing Inc., Marshfield, Mass. pp. 127-148.

Jayawickrama, K.J.S. 1991. Rootstock effects on scion growth, sexual reproduction, nutrient and carbohydrate status and water potential in loblolly pine (Pinus taeda L.). M.S. thesis, North Carolina State University, Raleigh, N.C.

Jayawickrama, K.J.S., Jett, J.B., and McKeand, S.E. 1991. Rootstock effects in conifers: a review. New For. 5: 157-173.

Jett, J.B. 1986. Reaching full production: a review of seed orchard management in the southeastern United States. In Proceedings of the IUFRO Conference: A Joint Meeting of Working Parties on Breeding Theory (S2.04.02), Progeny Testing (S2.04.03) and Seed Orchards (S2.03.03), 12-17 Oct. 1986, Williamsburg, Va. Edited by R.J. Weir. North Carolina State University, Raleigh. pp. 34-58. [Limited distribution.]

Karlsson, I., and Woods, J.H. 1992. Effects of rootstock source on the size, cone production and compatibility of Douglas-fir grafts. West. J. Appl. For. 7: 73-77.

Layne, R.E.C., Jackson, H.O., and Stroud, F.D. 1977. Influence of peach seedling rootstocks on defoliation and cold hardiness of peaches. J. Am. Soc. Hortic. Sci. 102: 89-92.

McKinley, C.R. 1975. Growth of loblolly scion material on rootstocks of known genetic origin. In Proceedings of the 13th Southern Forest Tree Improvement Conference, 10-11 June 1975, Raleigh, N.C. Eastern Tree Seed Laboratory, USDA Forest Service, Box 819, Macon, Ga. pp. 230-233.

Melchior, G.H. 1984. The influence of defined rootstocks on grafts of Norway spruce (Picea abies L. Karst). Silvae Genet. 33: 28-32.

Melchior, G.H. 1987. Increase of flowering in Norway spruce (Picea abies) by known rootstocks and planting grafts in southern sites. For. Ecol. Manage. 19: 23-33.

Moore, C.S. 1975. Relative importance of rootstock and scion in determining growth and fruiting in young apple trees. Ann. Bot. 39: 113-123.

Rives, M. 1971. Statistical analysis of rootstock experiments as providing a definition of the terms vigour and affinity in grapes. Vitis, 9: $280-290$.

Rom, R.C., and Carlson, R.F. (Editors). 1987. Rootstocks for fruit crops. John Wiley \& Sons, Inc., New York.

Roose, M.L., Cole, D.A., Atkin, D., and Kupper, R.S. 1989. Yield and tree size of four citrus cultivars on 21 rootstocks in California. J. Am. Soc. Hortic. Sci. 114: 678-684.

SAS Institute Inc. 1989. SAS/STAT guide for personal computers, version 6, edition 4, 2 vols. SAS Institute Inc., Cary, N.C.

Schmidtling, R.C. 1983a. Rootstock influences flowering, growth and survival of loblolly pine grafts. For. Sci. 29: 117-124.

Schmidtling, R.C. 1983b. Geographic location affects flowering of loblolly pine. In Proceedings of the 17th Southern Tree Improvement Conference, 7-9 June 1983, University of Georgia, Athens, Ga. Eastern Tree Seed Laboratory, USDA Forest Service, Box 819, Macon, Ga. pp. 42-48.

Schmidtling, R.C. 1988. Influence of rootstock on flowering, growth and foliar nutrients of slash pine grafts. In Proceedings of the 10th North American Forest Biology Workshop, 20-22 July 1988, Vancouver, B.C. Edited by J. Worrall, J. Loo-Dinkins, and D.P. Lester. pp. 120-127.

Sniezko, R.A. 1986. Influence of Pinus taeda rootstock on growth and cone production of P. kesiya and P. elliottii clones. In Proceedings of the IUFRO Conference: A Joint Meeting of Working 
Parties on Breeding Theory ( S2. 04. 02), Progeny Testing (S2.04.03) and Seed Orchards (S2. 03.03), 12-17 Oct. 1986, Williamsburg, Va. Edited by R.J. Weir. North Carolina State University, Raleigh. pp. 429-439. [Limited distribution.]

van den Driessche, R. 1974. Reciprocal grafting between three spruce species. N.Z. J. For. Sci. 4: 448-453.

Vyvyan, M.C. 1934. The distribution of growth between roots, stems and leaves in a young apple and its possible bearing on the problem on tree vigour. Report of the East Malling Research Station, East Malling, U.K. pp. 122-131.

Westwood, M.N. 1970. Rootstock-scion relationships in hardiness of deciduous fruit trees. HortScience, 5: 418-421.

Westwood, M.N., Roberts, A.N., and Bjornstad, H.O. 1976. Com- parison of Mazzard, Mahaleb and hybrid rootstocks for "Montmorency" cherry (Prunus cerasus L.) J. Am. Soc. Hortic. Sci. 101: 268-269.

White, G., Lowe, W.J., and Wright, J. 1983. Paraffin grafting techniques for loblolly pine. South. J. Appl. For. 7: 116-118.

White, J.W., and Castillo, J.A. 1989. Relative effect of root and shoot genotypes on yield of common bean under drought stress. Crop Sci. 29: 360-362.

Wutscher, H.K. 1989. Alteration of fruit tree nutrition through rootstocks. HortScience, 24: 578-584.

Young, E., and Houser, J. 1980. Influence of Siberian C rootstock on peach bloom delay, water potential, and pollen meiosis. J. Am. Soc. Hortic. Sci. 105: 242-245. 